\title{
Olopatadine Hydrochloride
}

National Cancer Institute

\section{Source}

National Cancer Institute. Olopatadine Hydrochloride. NCI Thesaurus. Code C61867.

The hydrochloride salt form of olopatadine, a dual action selective histamine $\mathrm{H} 1$ receptor antagonist and mast cell stabilizer with anti-allergic activity. Olopatadine stabilizes mast cells and prevents histamine release from mast cells. In addition, this agent also blocks histamine $\mathrm{H} 1$ receptors, thereby preventing histamine from binding to these receptors. Both actions prevent the effects of histamine on capillaries, bronchial smooth muscle, and gastrointestinal (GI) smooth muscle, including histamine-induced vasodilation, increased capillary permeability, bronchoconstriction, and spasmodic contraction of Gl smooth muscle. This drug also prevents histamine-induced pain and itching of mucous membranes. 